\title{
La collégiale de Saint-Quentin (Aisne)
}

\section{Christian Sapin}

\section{(2) OpenEdition}

\section{Journals}

\section{Édition électronique}

URL : https://journals.openedition.org/cem/5832

DOI : $10.4000 /$ cem.5832

ISSN : 1954-3093

\section{Éditeur}

Centre d'études médiévales Saint-Germain d'Auxerre

\section{Édition imprimée}

Date de publication : 15 août 2008

ISSN : 1623-5770

\section{Référence électronique}

Christian Sapin, «La collégiale de Saint-Quentin (Aisne) », Bulletin du centre d'études médiévales d'Auxerre | BUCEMA [En ligne], 12 | 2008, mis en ligne le 03 septembre 2008, consulté le 22 septembre 2022. URL : http://journals.openedition.org/cem/5832 ; DOI : https://doi.org/10.4000/cem.5832

Ce document a été généré automatiquement le 22 septembre 2022.

\section{(c) (i) (2)(2)}

Creative Commons - Attribution - Pas d'Utilisation Commerciale - Partage dans les Mêmes Conditions 4.0 International - CC BY-NC-SA 4.0

https://creativecommons.org/licenses/by-nc-sa/4.0/ 


\title{
La collégiale de Saint-Quentin (Aisne)
}

\author{
Christian Sapin
}

La quatrième campagne de recherche sur le site de la collégiale de Saint-Quentin ${ }^{1}$ a porté sur la fin de l'examen de la fosse d'inhumation redécouverte dans la partie occidentale de la crypte archéologique, réalisée au XIX siècle, sur les relations stratigraphiques à son environnement immédiat, ainsi que sur la position des sarcophages au sud. Il en ressort une occupation désormais attestée dès le IV ${ }^{\mathrm{e}}$ siècle analyses radiocarbone sur les charbons de bois dans les mortiers et sur les vestiges de la structure en bois autour de la tombe primitive - et non à partir du $\mathrm{VI}^{\mathrm{e}}$ siècle comme pouvait le laisser entendre, jusqu'à présent, la seule lecture des sources textuelles et de Grégoire de Tours. Par ailleurs, on assiste à la confirmation d'une monumentalisation précoce et progressive de la partie occidentale, autour de la tombe, avec une structuration très nette de l'espace liturgique, en relation avec le sanctuaire construit à chevet plat, restitué pour le VII siècle. Si des incertitudes demeurent sur l'enchaînement précis de ces phases, entre les $\mathrm{V}^{\mathrm{e}}$ et $\mathrm{VII}{ }^{\mathrm{e}}$ siècles, il est désormais clair que les étapes carolingiennes correspondent à deux états successifs de modification du 
sanctuaire et de ses niveaux, avec la création d'une crypte annulaire reconnue dans la campagne précédente.

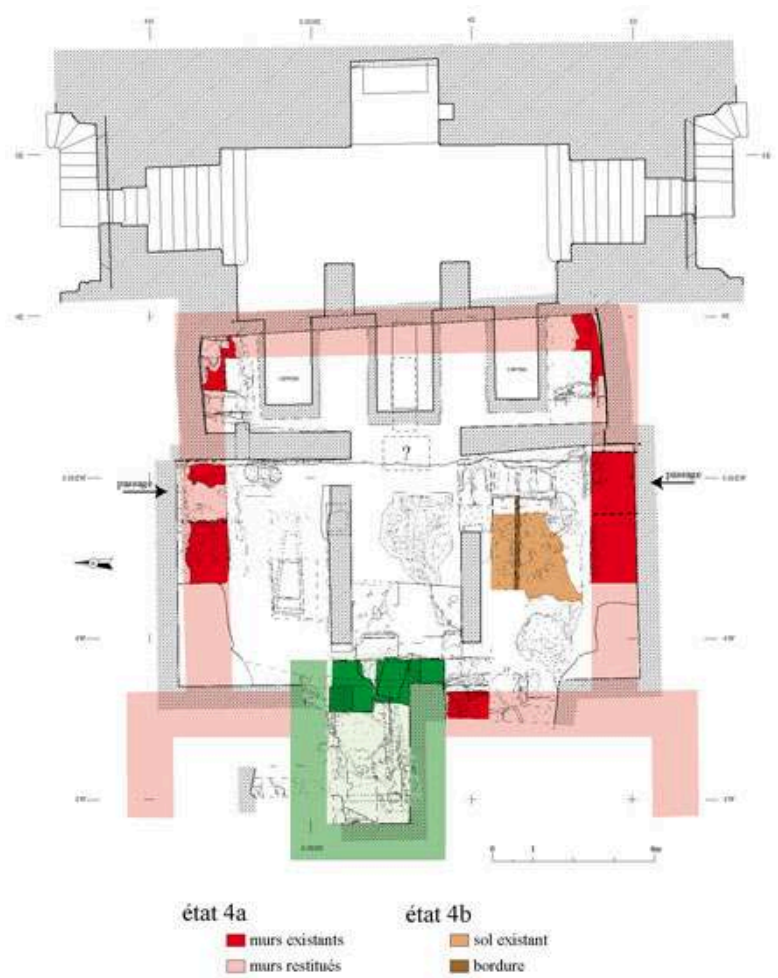

état restitué du chevet VII siècle (CEM, G. Fèvre, 2007).

Fig. 1. Saint-Quentin, collégiale, plan,

\section{NOTES}

1. Opération archéologique gérée par le CEM/Auxerre.

\section{INDEX}

Mots-clés : collégiale

Index géographique : France/Saint-Quentin 